\title{
Analisis Faktor yang Berpengaruh terhadap Terjadinya Erosi Serviks pada Wanita Pasangan Usia Subur (PUS) di Puskesmas Pallangga Kabupaten Gowa
}

\author{
Merlis Simon $^{1 *}$ \\ 1*. STIKES Papua, Jl. Kanal Victory Km.10, Kota Sorong, Indonesia, 98416 \\ *e-mail: merlis.simon04@gmail.com
}

(Received: 04-12-2019; Reviewed: 07-12-2019; Accepted: 26-12-2019)

\begin{abstract}
Women in carrying out their reproductive roles can not be separated from various problems, the most mild to severe disorders. And one of the disorders that attacks the female reproductive organs is cervical erosion. Cervical erosion is an inflammatory process or a wound that occurs in the cervical portion of the uterus (cervix). This study aims to analyze the factors that influence cervical erosion in women of childbearing age in Pallangga Health Center, Gowa Regency. This research is an analytic survey research with cross sectional research design. The population of all couples of childbearing age, especially women who do IVA examination with a sample of 154 respondents. This research data management uses a computerized system with the help of SPSS program. The conclusion of this study is that there is an influence between the age of first marriage, the use of contraceptives in the uterus, the use of oral contraceptives and the cleanliness of the reproductive organs against cervical erosion while parity does not affect the occurrence of cervical erosion. Suggestions for health workers to be more active in providing health education about prevention of cervical erosion and for all women to routinely check themselves to prevent cervical erosion.
\end{abstract}

Keywords: Age, Cervical Erosion, Contracepti, Genetal Organs, Parity

\begin{abstract}
Abstrak
Wanita dalam menjalankan peran reproduksinya tidak dapat terlepas dari berbagai permasalahan, gangguan yang paling ringan sampai dengan gangguan berat. Dan yang menjadi salah satu gangguan yang menyerang organ reproduksi wanita yaitu erosi serviks. Erosi serviks adalah suatu proses peradangan atau suatu luka yang terjadi pada daerah porsio serviks uteri (mulut rahim). Penelitian ini bertujuan untuk menganalisis faktor yang berpengaruh terhadap terjadinya erosi serviks pada wanita pasangan usia subur di Puskesmas Pallangga Kabupaten Gowa. Penelitian ini merupakan penelitian survey analitik dengan desain penelitian cross sectional. Populasi semua pasangan usia subur khususnya wanita yang melakukan pemeriksaan IVA dengan jumlah Sampel sebanyak 154 responden. Pengelolahan data penelitian ini menggunakan sistem komputerisasi dengan bantuan program SPSS. Kesimpulan dari penelitian ini adalah ada pengaruh antara usia pertama kali menikah, penggunaan alat kontrasepsi dalam rahim, penggunaan kontrasepsi oral dan kebersihan organ reproduksi terhadap terjadinya erosi serviks sedangkan paritas tidak berpengaruh terhadap terjadinya erosi serviks. Saran bagi petugas kesehatan untuk lebih aktif dalam memberikan pendidikan kesehatan tentang pencegahan erosi serviks dan bagi seluruh wanita untuk rutin memeriksakan diri untuk mencegah terjadinya erosi serviks.
\end{abstract}

Kata Kunci : Erosi Serviks, Genetalia, Kontrasepsi, Paritas, Usia 


\section{Pendahuluan}

Kanker serviks merupakan penyakit keganasan yang terjadi pada leher rahim. Penyakit ini didahului dengan kondisi lesi pra-kanker leher rahim atau erosi serviks yaitu adanya displasia/neoplasia intraepitel serviks (NIS). Erosi serviks atau lesi pra kanker serviks merupakan tanda awal terjadinya kanker serviks. Penyakit kanker leher rahim sejak timbulnya dysplasia hingga timbulnya carcinoma in situ membutuhkan waktu bertahun-tahun. Penyakit ini meningkat dalam kejadian dan sebagai penyebab kematian tertinggi pada wanita usia subur di dunia, serta menjadi masalah kesehatan utama bagi perempuan di Indonesia. Dapat sembuh jika penyakit ini dideteksi pada stadium awal yaitu dalam tahap lesi pra-kanker (Suwiyoga, 2010).

Data Globol tahun 2012 menyebutkan kanker di seluruh dunia mencapai 530.232 kasus dan di Asia dilaporkan 312.990 adalah kasus kanker leher rahim (59\%) dari jumlah global maupun di Asia, 50\% kasus mengalami kematian. Laporan WHO menyatakan, tiap tahun terjadi 500.000 kasus baru kanker leher rahim di dunia, sekitar 266.000 berakhir dengan kematian, dan hampir 87\% kasus terjadi di Negara berkembang (WHO/ICO, 2013). Kemenkes (2015), menuliskan kanker serviks merupakan penyakit dengan prevalensi tertinggi di Indonesia pada Tahun 2013 sebesar 0,8\%. Di Indonesia 15.000 kasus baru kanker leher rahim terjadi setiap tahunnya, sedangkan angka kematiannya 7.500 kasus per tahun. Pada tahun 2009, kasus baru kanker leher rahim berjumlah 2.429 atau sekitar 25,91\% dari seluruh kanker yang ditemukan di Indonesia. (Suwiyoga, 2010).

Dalam upaya mengurangi hasil positif palsu pada temuan IVA, dapat digunakan dengan menggunakan penapisan dua tahap yaitu menggunakan metode IVA dan Pap smear untuk meminimalkan hasil positif palsu dan pernah dilakukan penelitian oleh Abidin pada divisi Obstetri Ginekologi, Fakultas Kedokteran Universitas Indonesia, yaitu dengan menggunakan tehnik IVA dan servikografi, dengan cara ini dikatakan efektif untuk menekan hasil positif palsu (Abidin, 2014. Penelitian di luar negeri, dengan pemeriksaan menggunakan dua metode skrining menunjukkan efektivitas yang baik, dari pada dilakukan dengan satu metode pemeriksaan saja.

Berdasarkan data yang diperoleh dari Puskesmas Pallangga Gowa tentang kejadian erosi serviks pada ibu dimana jumlah penderita erosi serviks selalu mengalami peningkatan dari tahun ke tahun. Pada tahun 2013 jumlah ibu yang datang memeriksakan diri ke Puskesmas Pallangga Gowa sebanyak 335 pasien dan berdasarkan hasil pemeriksaan sekitar 98 pasien yang mengalami erosi serviks, sedangkan pada tahun 2014 jumlah ibu yang datang memeriksakan diri ke Puskesmas Pallangga Gowa sebanyak 355 pasien dan berdasarkan hasil pemeriksaan sekitar 123 pasien yang mengalami erosi serviks, sementara pada bulan Maret - Juni tahun 2015 tercatat 499 jumlah ibu yang datang memeriksakan diri ke Puskesmas Pallangga Gowa dan berdasarkan hasil pemeriksaan IVA terdapat sekitar 154 ibu yang telah melakukan pemeriksan IVA dimana dari 154 ibu ini ada yang mengalami erosi serviks dan ada pula yang tidak mengalami erosi serviks. Dan juga sudah ada beberapa ibu yang kembali memeriksakan dirinya ke puskesmas pallangga gowa telah didiagnosis terkena kanker serviks dan telah diberikan surat rujukkan untuk memeriksakan diri kerumah sakit untuk pengobatan lebih lanjut. Berdasarkan latar belakang tersebut dan tingginya jumlah wanita yang menderita erosi serviks di Puskesmas Pallangga Gowa maka penulis tertarik untuk meneliti lebih jauh tentang analisis faktor yang berpengaruh terhadap terjadinya erosi serviks pada wanita pasangan usia subur di Puskesmas Pallangga Kabupaten Gowa.

\section{Metode}

Penelitian ini merupakan survei analitik. Desain penelitan ini adalah cross sectional yaitu suatu penelitian untuk mempelajari dinamika korelasi antara factor-faktor risiko dengan efek, dengan cara pendekatan observasi atau pengumpulan data sekaligus pada saat bersamaan. Penelitian ini telah dilaksanakan di Puskesmas Pallangga Kabupaten Gowa. Pengambilan data dan penelitian ini dilakukan pada tanggal 13-30 September 2016. Populasi dalam penelitian ini adalah semua pasangan usia subur khususnya wanita yang melakukan pemeriksaan IVA di Puskesmas Pallangga Kabupaten Gowa pada bulan Maret-Juni 2015 sebanyak 154 orang. Sampel dalam penelitian ini adalah semua pasangan usia subur khususnya wanita yang melakukan pemeriksaan IVA di Puskesmas Pallangga Kabupaten Gowa sebanyak 154 orang.

Pengumpulan data dalam penelitian ini diperoleh dari hasil data awal yang diperoleh dari puskesmas dan disesuaikan dengan data yang diperoleh saat penelitian kemudian data diperiksa dengan tepat data tersebut. Setelah memeriksa data kemudian data diberi kode supaya memudahkan saat pengolahan data,kemudian memindahkan data ke dalam suatu media yang mudah ditangani untuk pengolahan data selanjutnya.menyusun dan mengorganisir data sedemikian rupa, sehingga akan dapat dengan mudah dapat diolah.

Analisa data dalam penelitian ini ada tiga analisa yang pertama yaitu analisa univariat dimana data yang termasuk dalam analisa univariat ialah karakteristik responden (usia, pendidikan dan pekerjaan wanita pasangan usia subur), dan variabel yang diteliti (usia saat pertama kali menikah, paritas, penggunaan AKDR, penggunaan kontrasepsi oral, dan kebersihan organ reproduksi), analisa yang kedua yaitu analisa bivariat digunakan untuk mengetahui pengaruh antara variabel independen usia saat pertama kali menikah, paritas, penggunaan AKDR, penggunaan kontrasepsi oral, dan kebersihan organ reproduksi serta variabel dependen yaitu erosi serviks, dan analisa yang ketiga yaitu analisa multivariat digunakan untuk mengetahui keeratan hubungan antara variabel 
independen dengan variabel dependen serta sub variabel independen yang paling berpengaruh dengan variabel dependen dan variabel independen yang paling berpengaruh yaitu penggunaan alat kontrasepsi dalam rahim (AKDR).

\section{Hasil}

1. Analisis univariat

a. Usia

Tabel 1. Distribusi frekuensi usia pasangan usia subur (PUS) di puskesmas pallangga kabupaten gowa

\begin{tabular}{ccc}
\hline Usia & n & \% \\
\hline $17-20$ & 3 & 1,9 \\
$21-25$ & 10 & 6,4 \\
$26-30$ & 13 & 8,4 \\
$31-35$ & 38 & 24,6 \\
$36-40$ & 32 & 20,7 \\
$41-45$ & 39 & 25,3 \\
$>46$ & 19 & 12,3 \\
\hline Jumlah & 154 & 100 \\
\hline
\end{tabular}

Tabel 1 menunjukkan karakteristik responden berdasarkan usia, dimana usia responden 17-20 tahun sebanyak 3 (1,9\%), usia 21-25 tahun sebanyak 10 (6,4\%), usia 26-30 sebanyak 13 (8,4\%), usia 31-35 tahun sebanyak $38(24,6 \%)$, usia 36-40 sebanyak 32 (20,7\%), usia 41-45 tahun sebanyak $39(25,3 \%)$ dan usia > 46 sebanyak $19(12,3 \%)$.

b. Pendidikan

Tabel 2. Distribusi frekuensi pendidikan pasangan usia subur (PUS) di puskesmas pallangga kabupaten gowa

\begin{tabular}{ccc}
\hline Pendidikan & n & \% \\
\hline SD & 5 & 3,2 \\
SMP & 69 & 44,8 \\
SMA & 62 & 40,8 \\
S1 & 17 & 11,0 \\
S2 & 1 & 0,6 \\
\hline Jumlah & 154 & 100 \\
\hline
\end{tabular}

Tabel 2 menunjukan karakteristik pendidikan responden SD sebanyak 5 , SMP sebanyak 69, SMA sebanyak 62, S1 sebanyak 17 dan S2 sebanyak 1.

c. Pekerjaan

Tabel 3. Distribusi frekuensi pekerjaan pasangan usia subur (PUS) di puskesmas pallangga kabupaten gowa

\begin{tabular}{lcc}
\hline \multicolumn{1}{c}{ Pekerjaan } & n & \% \\
\hline PNS & 4 & 2,6 \\
Karyawan Swasta & 10 & 6,5 \\
Wiraswasta & 2 & 1,3 \\
Petani & 13 & 8,4 \\
Pelajar/ Mahasiswa & 4 & 2,6 \\
Ibu Rumah Tangga & 121 & 78,6 \\
\hline \multicolumn{1}{c}{ Jumlah } & 154 & 100 \\
\hline
\end{tabular}

Tabel 3 menunjukan karakteristik pekerajaan responden dimana PNS sebanyak 4, karyawan swasta 10 , wiraswasta sebanyak 2 , petani sebanyak 13 , pelajar/mahasiswa sebanyak 4 , dan ibu rumah tangga sebanyak 121. 
d. Usia saat menikah

Tabel 4. Distribusi frekuensi usia saat menikah pasangan usia subur (PUS) di puskesmas pallangga kabupaten gowa

\begin{tabular}{ccc}
\hline Usia Saat Menikah & n & \% \\
\hline$\leq 20$ tahun & 131 & 85,1 \\
$>20$ tahun & 23 & 14,9 \\
\hline Jumlah & 154 & 100 \\
\hline
\end{tabular}

Tabel 4 menunjukan karakteristik usia saat menikah responden dimana $\leq 20$ tahun sebanyak 131 , $>20$ tahun sebanyak 23 .

e. Paritas

Tabel 5. Distribusi frekuensi paritas pasangan usia subur (PUS) di puskesmas pallangga kabupaten gowa

\begin{tabular}{ccc}
\hline Paritas & n & \% \\
\hline$>3$ kali & 151 & 98,1 \\
$\leq 3$ kali & 3 & 1,9 \\
\hline Jumlah & 154 & 100 \\
\hline
\end{tabular}

3.

Tabel 5 menunjukan karakteristik paritas responden dimana > 3 kali sebanyak 151, $\leq 3$ kali sebanyak

f. Penggunaan AKDR

Tabel 6. Distribusi frekuensi penggunaan akdr pasangan usia subur (PUS) di puskesmas pallangga kabupaten gowa

\begin{tabular}{ccc}
\hline Penggunaan AKDR & n & \% \\
\hline$\geq 4$ tahun & 115 & 74,7 \\
$<4$ tahun & 39 & 25,3 \\
\hline Jumlah & 154 & 100 \\
\hline
\end{tabular}

Tabel 6 menunjukan karakteristik penggunaan AKDR responden dimana $\geq 4$ tahun sebanyak 115, $<4$ tahun sebanyak 39 .

g. Penggunaan Kontrasepsi Oral

Tabel 7. Distribusi frekuensi penggunaan kontrasepsi oral pasangan usia subur (PUS) di puskesmas pallangga kabupaten gowa

\begin{tabular}{ccc}
\hline Penggunaan Kotrasepsi Oral & n & \% \\
\hline$\geq 5$ tahun & 78 & 50,6 \\
$<5$ tahun & 76 & 49,4 \\
\hline Jumlah & 154 & 100 \\
\hline
\end{tabular}

Tabel 7 menunjukan karakteristik penggunaan kontrasepsi oral responden dimana $\geq 5$ tahun sebanyak $78,<5$ tahun sebanyak 76 .

h. Kebersihan Organ Genetalia

Tabel 8. Distribusi frekuensi kebersihan organ genetalia pasangan usia subur (PUS) di puskesmas pallangga kabupaten gowa

\begin{tabular}{ccc}
\hline Kebersihan Organ Genetalia & n & \% \\
\hline Baik & 122 & 79,2 \\
Tidak & 32 & 20,8 \\
\hline Jumlah & 154 & 100
\end{tabular}

Tabel 8 menunjukan karakteristik kebersihan organ genetalia responden dimana Baik sebanyak 122, Tidak sebanyak 32 . 
i. Pemeriksaan IVA

Tabel 9. Distribusi frekuensi pemriksaan iva pasangan usia subur (PUS) di puskesmas pallangga kabupaten gowa

\begin{tabular}{ccc}
\hline Pemeriksaan IVA & n & \% \\
\hline Baik & 122 & 79,2 \\
Tidak & 32 & 20,8 \\
\hline Jumlah & 154 & 100 \\
\hline
\end{tabular}

Tabel 8 menunjukan karakteristik pemeriksaan IVA responden dimana Baik sebanyak 122 , Tidak sebanyak 32 .

2. Analisis Bivariat

a. Pengaruh usia saat menikah pada wanita pasangan usia subur (PUS) terhadap terjadinya erosi serviks

Tabel 10. Pengaruh usia saat menikah pada wanita pasangan usia subur (PUS) terhadap terjadinya erosi serviks di puskesmas pallanga kabupaten gowa

\begin{tabular}{|c|c|c|c|c|c|c|c|}
\hline \multirow{3}{*}{$\begin{array}{c}\text { Usia Pada Saat } \\
\text { Menikah }\end{array}$} & \multicolumn{4}{|c|}{ Pemeriksaan IVA } & \multirow{2}{*}{\multicolumn{2}{|c|}{ Total }} & \multirow{3}{*}{$\mathbf{P}$} \\
\hline & \multicolumn{2}{|c|}{ Erosi Serviks } & \multicolumn{2}{|c|}{ Tidak } & & & \\
\hline & $\mathbf{n}$ & $\%$ & $\mathbf{n}$ & $\%$ & $\mathbf{n}$ & $\%$ & \\
\hline Risiko Tinggi & 106 & 89,1 & 13 & 10,9 & 119 & 100,0 & \\
\hline Risiko Rendah & 25 & 71,4 & 10 & 28,6 & 35 & 100,0 & 0,021 \\
\hline
\end{tabular}

Tabel 10 menunjukkan bahwa usia pada saat menikah yang risiko tinggi (responden yang menikah pada usia $\leq 20$ tahun) yang telah melakukan pemeriksaan IVA dan mengalami erosi serviks sebanyak 106 dan responden yang tidak mengalami erosi serviks sebanyak 13, sedangkan responden usia pada saat menikah risiko rendah (responden yang menikah pada usia > 20 tahun) yang telah melakukan pemeriksaan IVA dan mengalami erosi serviks sebanyak 25 dan tidak mengalami erosi serviks sebanyak 10.

Hasil uji chi square diperoleh $\mathrm{p}=0,021(\mathrm{p}<0,05)$ yang berarti Ho diterima. Hal ini menunjukkan bahwa ada pengaruh usia saat menikah dengan terjadinya erosi serviks.

b. Pengaruh paritas pada wanita pasangan usia subur (PUS) terhadap terjadinya erosi serviks

Tabel 11. Pengaruh paritas pada wanita pasangan usia subur (PUS) terhadap terjadinya erosi serviks di puskesmas pallanga kabupaten gowa

\begin{tabular}{|c|c|c|c|c|c|c|c|}
\hline \multirow{3}{*}{ Paritas } & \multicolumn{4}{|c|}{ Pemeriksaan IVA } & \multirow{2}{*}{\multicolumn{2}{|c|}{ Total }} & \multirow{3}{*}{$\mathbf{P}$} \\
\hline & \multicolumn{2}{|c|}{ Erosi Serviks } & \multicolumn{2}{|c|}{ Tidak } & & & \\
\hline & $\mathbf{n}$ & $\%$ & $\mathbf{n}$ & $\%$ & $\mathbf{n}$ & $\%$ & \\
\hline Risiko Tinggi & 118 & 99,2 & 1 & 0,8 & 119 & 100,0 & 0255 \\
\hline Risiko Rendah & 33 & 94,3 & 2 & 5,7 & 35 & 100,0 & U, 2J5 \\
\hline
\end{tabular}

Tabel 11 menunjukkan bahwa responden paritas risiko tinggi (responden yang melahirkan > 3 kali) yang telah melakukan pemeriksaan IVA dan mengalami erosi serviks sebanyak 118 dan yang tidak mengalami erosi serviks sebanyak 1 Sedangkan paritas yang risiko rendah (responden yang melahirkan $\leq$ 3 kali) yang telah melakukan pemeriksaan IVA dan mengalami erosi serviks sebanyak 33 dan yang tidak mengalami erosi serviks sebanyak 2.

Hasil uji chi square diperoleh $\mathrm{p}=0,255(\mathrm{p}<0,05)$ yang berarti Ho ditolak dan Ha diterima. Hal ini menunjukkan bahwa tidak ada pengaruh paritas dengan terjadinya erosi serviks.

c. Pengaruh penggunaan AKDR pada wanita pasangan usia subur (PUS) terhadap terjadinya erosi serviks

Tabel 12. pengaruh penggunaan akdr pada wanita pasangan usia subur (PUS) terhadap terjadinya erosi serviks di puskesmas pallangga kabupaten gowa

\begin{tabular}{|c|c|c|c|c|c|c|c|}
\hline \multirow{3}{*}{ Penggunaan AKDR } & \multicolumn{4}{|c|}{ Pemeriksaan IVA } & \multirow{2}{*}{\multicolumn{2}{|c|}{ total }} & \multirow{3}{*}{$\mathbf{p}$} \\
\hline & \multicolumn{2}{|c|}{ Erosi Serviks } & \multicolumn{2}{|c|}{ Tidak } & & & \\
\hline & $\mathbf{n}$ & $\%$ & $\mathbf{n}$ & $\%$ & $\mathbf{n}$ & $\%$ & \\
\hline Risiko Tinggi & 109 & 91,6 & 10 & 8,4 & 119 & 100,0 & مOمO م \\
\hline Risiko Rendah & 6 & 17,1 & 29 & 82,9 & 35 & 100,0 & 0,000 \\
\hline
\end{tabular}

Tabel 12 menunjukkan bahwa penggunaan AKDR yang risiko tinggi (responden yang menggunakan AKDR selama $\geq 4$ tahun) yang telah melakukan pemeriksaan IVA dan mengalami erosi serviks sebanyak 109 dan tidak mengalami erosi serviks sebanyak 10 , Sedangkan penggunaan AKDR yang risiko rendah (responden yang menggunakan AKDR < 4 tahun) yang telah melakukan pemeriksaan IVA dan mengalami erosi serviks sebanyak 6 dan tidak mengalami erosi serviks terdapat 29. 
Hasil uji chi square diperoleh $\mathrm{p}=0,000(\mathrm{p}<0,05)$ yang berarti Ho diterima. Hal ini menunjukkan bahwa ada pengaruh lama penggunaan AKDR dengan terjadinya erosi serviks.

d. Pengaruh penggunaan alat kontrasepsi oral pada wanita pasangan usia subur (PUS) terhadap terjadinya erosi serviks

Tabel 13. pengaruh penggunaan alat kontrasepsi oral pada wanita pasangan usia subur (PUS) terhadap terjadinya erosi serviks di puskesmas pallangga kabupaten gowa

\begin{tabular}{|c|c|c|c|c|c|c|c|}
\hline \multirow{3}{*}{$\begin{array}{l}\text { Penggunaan Alat } \\
\text { Kontrasepsi Orat }\end{array}$} & \multicolumn{4}{|c|}{ Pemeriksaan IVA } & \multirow{2}{*}{\multicolumn{2}{|c|}{ Total }} & \multirow{3}{*}{$\mathbf{P}$} \\
\hline & \multicolumn{2}{|c|}{ Erosi Serviks } & \multicolumn{2}{|c|}{ Tidak } & & & \\
\hline & $\mathbf{n}$ & $\%$ & $\mathbf{n}$ & $\%$ & $\mathbf{n}$ & $\%$ & \\
\hline Risiko Tinggi & 48 & 40,3 & 71 & 59,7 & 119 & 100,0 & \multirow{2}{*}{0,000} \\
\hline Risiko Rendah & 30 & 85,7 & 5 & 14,3 & 35 & 100,0 & \\
\hline
\end{tabular}

Tabel 13 menunjukkan bahwa Penggunaan Alat Kontrasepsi Oral risiko tingi (responden yang menggunakan kontrasepsi oral dalam waktu $\geq 5$ tahun) yang telah melakukan pemeriksaan IVA dan mengalami erosi serviks sebanyak 48 dan yang tidak mengalami erosi serviks sebanyak 71 responden, Sedangkan Penggunaan Alat Kontrasepsi Oral risiko rendah (responden menggunakan kontrasepsi oral dalam waktu $<5$ tahun yang telah melakukan pemeriksaan IVA dan mengalami erosi serviks sebanyak 30 dan yang tidak mengalami erosi serviks sebanyak 5 .

Hasil uji chi square diperoleh $\mathrm{p}=0,000(\mathrm{p}<0,05)$ yang berarti Ho diterima. Hal ini menunjukkan bahwa ada pengaruh usia saat menikah dengan terjadinya erosi serviks

e. Pengaruh kebersihan organ reproduksi pada wanita pasangan usia subur (PUS) terhadap terjadinya erosi serviks

Tabel 14. pengaruh kebersihan organ reproduksi pada wanita pasangan usia subur (PUS) terhadap terjadinya erosi serviks di puskesmas pallangga kabupaten gowa

\begin{tabular}{|c|c|c|c|c|c|c|c|}
\hline \multirow{3}{*}{$\begin{array}{l}\text { Penggunaan Alat } \\
\text { Kontrasepsi Orat }\end{array}$} & \multicolumn{4}{|c|}{ Pemeriksaan IVA } & \multirow{2}{*}{\multicolumn{2}{|c|}{ Total }} & \multirow{2}{*}{$\mathbf{P}$} \\
\hline & \multicolumn{2}{|c|}{ Erosi Serviks } & \multicolumn{2}{|c|}{ Tidak } & & & \\
\hline & $\mathbf{n}$ & $\%$ & $\mathbf{n}$ & $\%$ & $\mathbf{n}$ & $\%$ & \\
\hline Risiko Tinggi & 119 & 100 & 0 & 0 & 119 & 100,0 & \multirow{2}{*}{0,045} \\
\hline Risiko Rendah & 3 & 8,6 & 32 & 91,4 & 35 & 100,0 & \\
\hline
\end{tabular}

Tabel 14 menunjukkan bahwa kebersihan organ reproduksi risiko tinggi yang telah melakukan pemeriksaan IVA dan mengalami erosi serviks sebanyak 119 dan tidak ada yang mengalami erosi serviks, sedangkan responden dengan kebersihan organ reproduksi risiko rendah yang telah melakukan pemeriksaan IVA dan mengalami erosi serviks sebanyak 3 dan yang tidak mengalami erosi serviks sebanyak 32 .

Hasil uji chi square diperoleh $\mathrm{p}=0,000(\mathrm{p}<0,05)$ yang berarti Ho diterima. Hal ini menunjukkan bahwa ada pengaruh kebersihan organ reproduksi dengan terjadinya erosi serviks.

3. Analisis Multivariat

Tabel 15 hasil analisis bivariat usia saat menikah, paritas, penggunaan akdr, penggunaan kontrasepsi oral dan kebersihan organ reproduksi pada wanita pasangan usia subur (PUS) terhadap terjadinya erosi serviks di puskesmas pallanga kabupaten gowa

\begin{tabular}{cc}
\hline Variabel & $\mathbf{P}$ \\
\hline Usia saat menikah & $0,021^{*}$ \\
Paritas & 0,255 \\
Penggunaan AKDR & $0,000^{*}$ \\
Penggunaan Kontrasepsi oral & $0,000^{*}$ \\
Kebersihan Organ Reproduksi & $0,000^{*}$ \\
\hline *=kandidat yang masuk ke multivariate &
\end{tabular}

Tabel 15 menunjukkan bahwa terdapat empat variabel/sub variabel yang masuk dalam uji multivariat karena memiliki nilai $\mathrm{p}<0,25$ yaitu usia saat menikah, penggunaan AKDR, penggunaan kontrasepsi oral dan kebersihan organ reproduksi. 
Tabel 16. Hasil analisis regresi logistik variabel / sub variabel usia saat menikah, penggunaan akdr, penggunaan kontrasepsi oral dan kebersihan organ reproduksi pada wanita pasangan usia subur (PUS) terhadap terjadinya erosi serviks di puskesmas pallanga kabupaten gowa

\begin{tabular}{cccccc}
\hline Variabel & B & SE & Wald & P & Exp(B) \\
\hline Usia saat menikah & -2.677 & 1.273 & 4.421 & 0,006 & 0,069 \\
Penggunaan AKDR & 16.923 & $1.063 \mathrm{E} 4$ & 0,000 & 0.000 & $2.236 \mathrm{E} 7$ \\
Penggunaan Kontrasepsi oral & 1.292 & 1.283 & 1.013 & 0.294 & 3.639 \\
Kebersihan Organ Reproduksi & --41.739 & $1.259 \mathrm{E} 4$ & 0,000 & 0.000 & 0.000 \\
konstanta & 22.279 & $6.745 \mathrm{E} 3$ & 0,000 & 0.000 & $4.738 \mathrm{E} 9$ \\
\hline
\end{tabular}

Tabel 16 menunjukkan bahwa variabel yang paling berpengaruh terhadap terjadinya erosi serviks adalah penggunaan alat kontrasepsi dalam rahim ( AKDR ) dengan nilai $\mathrm{p}<0,000$.

\section{Pembahasan}

1. Pengaruh usia saat menikah terhadap terjadinya erosi serviks

Berdasarkan hasil penelitian yang telah dilakukan diperoleh hasil bahwa ada pengaruh usia saat menikah dengan terjadinya erosi serviks dengan nilai $\mathrm{p}=0,021(\mathrm{p}<0,05)$ dimana $89,1 \%$ responden yang menikah pada usai $\leq 20$ tahun yang telah melakukan pemeriksaan IVA mengalami erosi serviks.

Pada usia muda, sel-sel mukosa pada serviks belum matang. Umumnya sel-sel mukosa baru matang setelah wanita berusia 20 tahun ke atas. Akan berbeda hasilnya, bila hubungan seksual dilakukan diatas 20 tahun, dimana selse mukosa tidak lagi terlalu rentan terhadap perubahan. Pada usia $\leq 20$ tahun, sel-sel mukosa pada serviks belum matang, umumnya sel-sel mukosa baru matang setelah wanita berusia $>20$ tahun. Artinya sel mukosa yang belum matang masih rentan pada rangsangan sehingga belum siap menerima rangsangan dari luar, termasuk zat-zat kimia yang dibawa sperma, sehingga sel-sel mukosa dapat berubah sifat menjadi sel kanker. Melakukan hubungan seks tidak aman terutama pada usia muda memungkinkan terjadinya infeksi HPV.

Penelitian ini sejalan dengan penelitian yang dilakukan oleh Aulia $(\mathrm{OR}=4,42)$, Melva $(\mathrm{p}=0,000$, $\mathrm{OR}=2,330,95 \% \mathrm{CI}=1,619-3,352)$, Wasida $(\mathrm{p}=0,002)$ juga mendapatkan hasil yang sama, yaitu ada hubungan antara pernikahan kurang dari 20 tahun dengan kejadian prakanker serviks. Namun pada penelitian Ainiy $(\mathrm{p}=0,000, \mathrm{OR}=0,155)$, tidak terdapat perbedaan yang signifikan antara pernikahan kurang dari 20 tahun dengan kejadian prakanker serviks.

Berdasarkan hasil penelitian yang dilakukan oleh peneliti maka peneliti memberi pendapat bahwa menikah pada usia $\leq 20$ tahun dan $>20$ tahun sama-sama bisa mengalami erosi serviks tetapi yang lebih beresiko pada yang menikah pada usia $\leq 20$ tahun dengan alasan sistem reproduksinya belum matang untuk melakukan hubungan seksual lebih dini, salah satu cara untuk mencegah terjadinya erosi serviks berlanut ke tahap selanutnya yaitu tetap menjaga kebiasaan hidup yang baik dan bersih, dan juga melakukan pemeriksaan dini yaitu pemeriksaan pap smear atau pemeriksaan IVA.

2. Pengaruh paritas terhadap terjadinya erosi serviks

Berdasarkan hasil penelitian yang telah dilakukan diperoleh hasil bahwa tidak ada pengaruh paritas dengan terjadinya erosi serviks dengan nilai $\mathrm{p}=0,255(\mathrm{p}<0,05)$ dimana terdapat responden yang paritas $>3$ kali yang melakukan pemeriksaan IVA dan mengalami erosi serviks disebabkan karena kurangnya pemahaman responden tentang melahirkan lebih dari 3 kali akan mengakibatkan terjadinya erosi serviks karena jika melahirkan lebih dari 3 kali akan menyebabkan trauma pada serviks responden begitupula dengan yang paritas > 3 kali yang melakukan pemeriksaan IVA dan tidak mengalami erosi serviks disebabkan karena kurangnya pemahaman responden terhadap jumlah melahirkan yan benar.

Penelitian ini sejalan dengan teori dalam (Notoatmodjo,2010) yang menyatakan bahwa Paritas dapat dipengaruhi oleh beberapa faktor salah satunya adalah pendidikan. Pendidikan berarti bimbingan yang diberikan oleh seseorang terhadap perkembangan orang lain menuju ke arah suatu cita-cita tertentu. Makin tinggi tingkat pendidikan seseorang, maka makin mudah dalam memperoleh menerima informasi, sehingga kemampuan ibu dalam berpikir lebih rasional. Ibu yang mempunyai pendidikan tinggi akan lebih berpikir rasional bahwa jumlah anak yang ideal adalah 2 orang.

Penelitian ini juga sejalan dengan penelitian yang dilakukan oleh Syarifah di RSAB Muhammadiyah Gresik, dimana tidak terdapat hubungan antara paritas dengan kasus erosi serviks dengan nilai $p=0,331$. Hal tersebut berbeda dengan hasil penelitian yang dilakukan oleh Lestadi, menemukan lebih tinggi frekuensi kejadian erosi serviks pada pasien yang pernah melahirkan dari pada yang belum melahirkan.

Berdasarkan penelitian ini maka peneliti memberi pendapat bahwa paritas sangat dipengaruhi oleh pendidikan dimana dengan berpendidikan yang tinggi dapat berpikir secara rasional tentang jumlah anak yang diinginkan supaya tidak dapat risiko yang akan merugikan diri sendiri. 
3. Pengaruh penggunaan AKDR terhadap terjadinya erosi serviks

Berdasarkan hasil penelitian yang telah dilakukan diperoleh hasil bahwa ada pengaruh lama penggunaan AKDR dengan terjadinya erosi serviks dengan nilai $\mathrm{p}=0,000(\mathrm{p}<0,05)$ dimana terdapat responden yang menggunakan AKDR selama $\geq 4$ tahun yang telah melakukan pemeriksaan IVA dan mengalami erosi serviks ini disebabkan karena responden kebanyakkan mengeluh adanya kelainan yang dirasakan misalnya sering terjadi perdarahan diluar jadwal menstruasi dan rasa nyeri yang dirasakan pada organ repsroduksinya dan setelah dilakukan pemeriksaan ternyata terjadi peradangan pada serviks yang disebabkan oleh alat kontrasepsi dalam rahim, Sedangkan respoden yang menggunakan AKDR selama $\geq 4$ tahun yang telah melakukan pemeriksaan IVA dan tidak mengalami erosi serviks ini disebabkan karena responden mengetahui tindakan apa yang dilakukan jika menggunakan alat kontrasepsi dalam rahim yaitu dengan cara sering memeriksakan diri ke puskesmas sesuai denga jadwal yang telah ditentukan.

Dan juga sesuai dengan Teori Moya J Morison (2014), pada saat tindakan pemasangan AKDR mungkin terdapat sedikit luka atau erosi pada porsio, luka tersebut akan kembali pulih dalam jangka waktu 1 bulan. Sehingga jika erosi terjadi pada pemakaian lebih dari 1 bulan hal itu bukan disebabkan akibat tindakan pemasangan. Apabila terdapat erosi porsio pada akseptor dengan lama pemakaian AKDR lebih dari 1 tahun, hal tersebut mungkin dikarenakan adanya benang AKDR yang lama terdapat pada porsio yang dianggap sebagai benda asing oleh tubuh.

Berdasarkan penelitian ini maka peneliti memberi pendapat bahwa semakin lama penggunaan alat kontrasepsi dalam rahim maka kemungkinan besar peluang terjadinya erosi serviks semakin besar apalagi jika kurangnya motivasi untuk memeriksakannya ke puskesmas, oleh sebab itu jika penggunaan aat kontrasepsi dalam rahim digunakan maka usahakan sesering mungkin untuk melakukan pemeriksaan untuk mencegah terjadinya kelainan atau dampak yang akan mengganggu kesehatan.

4. Pengaruh penggunaan kontrasepsi oral terhadap terjadinya erosi serviks

Berdasarkan hasil penelitian yang telah dilakukan diperoleh hasil bahwa ada pengaruh penggunaan alat kontrasepsi oral dengan terjadinya erosi serviks dengan nilai $\mathrm{p}=0,000(\mathrm{p}<0,05)$. Penelitian ini sesuai dengan teori yang dikemukan oleh Megadhana (2014), bahwa kontrasepsi oral yang dipakai dalam jangka panjang lebih dari 4 tahun dapat meningkatkan risiko pra kanker leher rahim sebesar 1,5-2,5 kali. Risiko relatif pada pemakaian kontrasepsi oral sebesar 1,19 kali dan meningkat sesuai dengan lamanya pemakaian. Wanita pemakai pil KB harus rutin menjalani pemeriksaan pap smear (minimal 1 kali/tahun), selain itu wanita pemakai pil KB memiliki risiko kanker ovarium yang lebih rendah. Kontrasepsi oral yang digunakan secara luas dewasa ini umumnya merupakan kombinasi antara estrogen dan progestin. Kurang lebih 100 juta perempuan di seluruh dunia menggunakan kontrasepsi oral kombinasi. Pil kombinasi tersebut memiliki efektivitas tinggi dalam mencegah kehamilan yaitu sekitar 5 dari 100 perempuan pengguna pil kombinasi dan 1 dari 100 perempuan yang menggunakan kontrasepsi oral dengan sempurna mengalami kehamilan per tahun.

Berdasarkan penelitian ini maka peneliti memberi pendapat bahwa untuk mencegah terjadinya erosi serviks pada pengguna kontrasepsi oral harus rutin memeriksakan diri ke puskesmas untuk mengetahui efek dari kontraepsi oral yang digunakan.

5. Pengaruh kebersihan organ reproduksi terhadap terjadinya erosi serviks

Berdasarkan hasil penelitian yang telah dilakukan diperoleh hasil bahwa ada pengaruh kebersihan organ reproduksi dengan terjadinya erosi serviks dengan nilai $\mathrm{p}=0,000(\mathrm{p}<0,05)$ Terdapat pula responden yang kebersihan organ reproduksi kurang baik melakukan pemeriksaan IVA dan mengalami erosi serviks ini disebabkan karena kurangnya pemahaman pentingnya menjaga organ reproduksi dan juga disebabkan oleh lingkungan yang tidak mendukung kebersihannya misalnya air yang digunakaaa sn tidak masuk dalam jenis air bersih, pada saat membersihkan alat reproduksi asal membersihkan saja, dan juga kebanyakan responden saat menstruasi asal menggunakan pembalut tanpa melihat jenis atau bahan pembalut yang digunakan.

Penelitian ini sesuai dengan teori Wartonah (2010), bahwa personal higiene organ genital merupakan suatu tindakan untuk memelihara kebersihan dan kesehatan seseorang untuk kesejahteraan fisik dan psikis salah satunya kebersihan organ genitalia. Kebersihan organ dimana kebersihan memiliki pengaruh terhadap $\mathrm{Ph}$ vagina sehingga dapat memberikan peluang untuk pertumbuhan flora, dimana flora ini dapat memberikan perasaan gatal dan menggaruk sehingga timbul radang. Radang inilah yang kemungkinan mempercepat pertumbuhan HPV sehingga meningkatkan risiko terjadinya erosi serviks.

Berdasarkan hasil penelitian ini maka peneliti memberi pendapat bahwa untuk mencegah terjadinya erosi serviks sangat penting dalam menjaga kebersihan organ reproduksi dan mengetahui cara yang tepat dalam membersihkan dan juga mengetahui jenis atau bahan yang akan digunakan pada organ reproduski yang baik. 
6. Faktor yang paling berpengaruh terhadap terjadinya erosi serviks pada Pasangan usia subur di Puskesmas Pallangga Kabupaten Gowa.

Berdasarkan data statistik maka diketahui variabel yang paling berpengaruh terhadap terjadinya erosi serviks adalah penggunaan alat kontrasepsi dalam rahim ( AKDR ). Kajian menunjukkan bahwa penggunaan alat kontrasepsi dalam rahim ( AKDR ) merupakan faktor yang berpengaruh karena sebagian dari pasangan usia subur menggunakan alat kontrasepsi dalam rahim AKDR selama $\geq 4$ tahun.

\section{Kesimpulan}

Berdasarkan hasil penelitian tentang analisis faktor yang mempengaruhi terjadinya erosi serviks pada wanita pasangan usia subur di Puskesmas Pallangga Kabupaten Gowa yang telah dilakukan , maka dapat disimpulkan bahwa Ada pengaruh usia pada saat menikah terhadap terjadinya erosi serviks pada wanita pasangan usia subur di Puskesmas Pallangga Kabupaten Gowa, Tidak Ada pengaruh paritas terhadap terjadinya erosi serviks pada wanita pasangan usia subur di Puskesmas Pallangga Kabupaten Gowa, Ada pengaruh penggunaan AKDR terhadap terjadinya erosi serviks pada wanita pasangan usia subur di Puskesmas Pallangga Kabupaten Gowa, Ada pengaruh penggunaan kontrasepsi oral terhadap terjadinya erosi serviks pada wanita pasangan usia subur di Puskesmas Pallangga Kabupaten Gowa, Ada pengaruh kebersihan (hygiene) organ reproduksi terhadap terjadinya erosi serviks pada wanita pasangan usia subur di Puskesmas Pallangga Kabupaten Gowa, Faktor yang paling berpengaruh terhadap terjadinya erosi serviks pada wanita pasangan usia subur di Puskesmas Pallangga Kabupaten Gowa adalah penggunaan alat kontrasepsi dalam rahim (AKDR).

\section{Saran}

Berdasarkan kesimpulan dari hasil penelitian, maka saran yang dapat peneliti berikan untuk pelayanan kesehatan adalah Bagi Puskesmas Pallangga Kabupaten Gowa yaitu Peningkatan pengetahuan dan pemahaman masyarakat tentang erosi serviks melalui penyuluhan atau pendidikan kesehatan dan Melakukan pemeriksaan IVA rutin kepada masyarakat untuk mencegah terjadinya erosi serviks. Bagi Penderita erosi serviks yaitu Pencegahan risiko erosi serviks melalui Pendewasaan Usia Perkawinan (PUP) dan perencanaan jumlah anak yang ideal dalamkeluarga, Penanganan lebih lanjut terhadap kejadian erosi serviks melalui penyebaran informasi kepada ibu rumah tangga dimana informasi tersebut merupakan upaya untuk merendahkan angka kehamilan sehingga salah satu faktor risiko kanker leher rahim yaitu paritas dapat diatasi, Melakukan pemeriksaan pap smear guna mempermudah pengobatan dan mencegah petumbuhan erosi serviks ke stadium lanjut, Meminta zat anti kanker kepada dokter, apabila sudah menggunakan kontrasepi oral> 4 tahun dan ingin melanjutkan menggunakan kontrasepsi oral, Mengurangi peningkatan faktor risiko erosi serviks dengan menjaga kebersihan organ reproduksi dengan cara menggunakan air yang bersih saat membersihkan organ reproduksi, mengganti pembalut dan tidak menggunakan pembalut berdioksin saat menstruasi, mengurangi penggunaan pembersih (sabun) untuk organ reproduksi vagina. Bagi Peneliti Lain yaitu Untuk penelitian selanjutnya perlu dilakukan penelitian lebih lanjut dengan mengikutsertakan variabel lainnya yang belum diteliti yang mempengaruhi terjadinya erosi serviks misalnya variabel merokok, riwayat penyakit kelamin, sosial ekonomi dan pola makan.

\section{Referensi}

Abidin F. A. 2014. Efektivitas Gabungan pemeriksaan servik ograf idan tes inspeksi visual asam asetat pada wanita dengan Tes Inspeksi Visual Asam Asetat Positif Sebagai Usaha Penapisan Dua Tahap Dalam Deteksi Dini Lesi Pra Kanker Serviks. Tesis Universitas Indonesia. Retrieved at http://lib.ui.ac.id/opac/themes/libri2/detail.

Amin, Y., Mulawardhana P., \& Erawati, D. 2016. Demografi, Respon Terapi dan Survival Rate Pasien Kanker Serviks Stadium III-IVA yang Mendapat Kemoterapi Dilanjutkan Radioterapi. Retrieved http://ejournal.stikes-ppni.ac.id/index.php/JKS/article/view/200.

Cunningham G., Gant N. F.,Leveno K. J; Gilstrap L. C., Hauth J. C., Wenstrom K. D. 2013. Obstetri Williams. Jakarta: EGC.

Fitri, D. 2013. Hubungan Usia Wanita Saat Coitarche Dan Lamanya Pemakaian Pil KB Kombinasi Dengan Kejadian Kanker Serviks Di Posa RSUD. Dr. Soetomo Surabaya. Retrieved : http://adln.lib.unair.ac.id/go.

Gusti Agung. 2012. Pengaruh Paparan asap rokok dan higiene diri terhadapt terjadinya risiko lesi prakanker leher rahim di Kota Denpasar. Retrieved http://adln.lib.unair.ac.id/go. 
Guyton \& hall. 1997. Buku Ajar Fisiologi Kedokteran. Jakarta : $\quad$ EGC. http://blogzsalam.blogspot.co.id/2012/05/hormon-reproduksi-wanita.html

Handayani, S. 2010. Pelayanan Keluarga Berencana. Jakarta : Pustaka Rihama.

Harianto, R. M., \& Hery, S. 2005. Risiko penggunaan pil kontrasepsi kombinasi terhadap kejadian kanker payudara pada reseptor KB. Jakarta : Majalah Ilmu Kefarmasian.

Hidayat, A. A. 2006. Kebutuhan Dasar Manusia. Surabaya : Salemba Medika.

Ida, B. G. M. 2005. Ilmu Kebidanan, Penyakit Kandungan dan Keluarga Berencana Untuk pendidikan Bidan. Jakarta: EGC.

Ida, B., G. M. 2007. Kesehatan Wanita. Jakarta: EGC.

Kemenkes RI. 2015. Pusat Data Data Informasi.Infodatin Pusat Data dan Informasi Kementerian Kesehatan RI. STOP KANKER. Retrieved at www.depkes.go.id/resources/download/infodatin-kanker.pdf.

Kowari, M. 2016. Faktor Risiko Lesi Pra kanker Serviks Berdasarkan Hasil Pap Smear Di Klinik Kespro Yayasan Rama Sesana Periode 2013-2015. Skripsi Program Studi Ilmu Kesehatan Masyarakat Fakultas Kedokteran Universitas Udayana 2016. Retrieve at https://wisuda.unud.ac.id/pdf/1420015023-1.pdf.

Lestari, S., Kusumawati, Y., Werdani., K. 2016. eprints.ums.ac.id.

Naz, U., \&Hanif, S. 2014. Agreement Between Visual Inspection WihAceic Acid and Papanicolaou's Smear as Screening Methods for Cervical Cancer. Journal of The College of The Physicians and Surgeons Pakistan2014,Vol.24(4):228-231. Retrievedwww.jcpsp.pk/archive/2014/Apr2014/03.pdf.

Nugroho T, dkk. 2014. Masalah Kesehatan Reproduksi Wanita. Yogyakarta : Nuha Medika.

Padila. 2012. Keperawatan Medikal Bedah. Yogyakarta : Nuha Medika.

Parwati, N., Putra A. E., \& Karmaya, M. 2015. Kontrasepsi Hormonal dan Riwayat Infeksi Melular Seksual Sebagai Faktor Risiko Les iPra-kanker Leher Rahim. Laporan Hasil Penelitian. Public Health Preventive Medicine Archieve.Volume 3.Nomor 2 Desember 2015.

Proverawati, A., Islaely, A. D. 2010. Paduan Memilih Kontrasepsi. Jakarta : Nuha Medika.

Purwati, H. \& Janes, C. 2015. The Perception of Fertile Age Women, on Early Detection of Ca. Cervical With Visual Inspection With Acetic Acid Method at BPM Hj. Dyah Indrawati, SST, Tanjangrono Village, District Ngoro, Mojokerto. Retrieve at

Rahayu S. D. 2015. Asuhan Ibu Dengan Kanker Serviks. Jakarta : Salemba Medika.

Riksani R. 2016. Kenali Kanker Serviks Sejak Dini. Yogyakarta : Rapha Publishing.

Sarwono, P. 2005. Ilmu Kebidanan. Jakarta : YBPSP.

Saryono. 2011. Metodologi Penelitian Kesehatan. Jakarta : Mitra Cendikia.

Savitri A, dkk. 2015. Kupas Tuntas Kanker Payudara, Leher Rahim, dan Rahim. Yogyakarta : Pustaka baru press.

Sibagariang, E. E., Pusmaika, R., \& Rismalinda. 2010. Kesehatan Reproduksi. Jakarta : CV. Trans Info Media.

Situmorang F. E. 2014. Faktor-Faktor risiko Terjadinya Kanker Serviks di RSUP H. Adam Malik Medan. Fakultas Keperawatan Universitas Sumatera Utara.

Sudirtayasa, W. 2015. Hubungan Infeksi HIV Dengan Lesi Pra kanker Serviks. E-Journal Obstetric \& Ginecology Udayana Vol. 3, No. 5. Retrieve at http://ojs.unud.ac.id/index.php/obgyn/article/view/13495.

Sugiyono. 2015. Metode penelitian kuantitatif kualitatif dan $R \& D$. Bandung : Alfabeta. 
Sumartini S. H., \& Purnami, S. W. 2015. Penggunaan Classification and Regression Trees (CART) untuk Klasifikasi Rekurens iPasien Kanker Serviks di RSUD Dr. Soetomo Surabaya. Jurnal Sains dan Seni ITS Vol.5.No.2.http://www.ejurnal.its.ac.id/index.php/sains_seni/article/view/10673/2395.

Supardi, S \& Rustika. 2013. Buku Ajar Metodologi Riset Keperawatan. Jakarta : Trans Info Media.

Suriani. 2011. Faktor Risiko Lesi Pra kanker Leher Rahim pada PUS di Kecamatan Payangan Gianyar. Tesis Universitas Udayana Denpasar.

Susilo, H. W., \& Aima. H. M. 2013. Penelitian Dalam Ilmu Keperawatan: Pemahaman Dan Penggunaan Metode Kuantitatif Serta Aplikasi Dengan Program SPSS \& Lisrel. Jakarta : In Media.

Suwiyoga,IK. 2014. Beberapa Masalah Pap Smear Sebagai Alat Diagnosis Dini Kanker Serviks Di Indonesia. Jurnal Studi Jender Srikandi. Retrieved from URL : http: ojs.unud.ac.id/index.php/srikandi/article/view/2755.

Tatik Indrawati \& Heni Pitriyani . 2013. Hubungan Personal Higiene Organ Genetal dengan kejadian lesi pra kanker serviks di RSUP Dr. Kariadi Kota Semarang.

Retrieve at : http://www.ejurnal.com/2013/11/hubungan-personal-higiene-organ-genital.html

Tilong, A. D. 2012. Bebas Dari Ancaman Kanker Serviks. Jakarta : Flashbook.

Wahyuningsih, T. 2013. Faktor-Faktor Risiko Yang Berhubungan Dengan Kejadian Lesi Pra kanker Serviks Dalam Deteksi Dini Kanker Serviks Dalam Deteksi Dini Kanker Serviks Melalui Metode IVA (Inspeksi Visual Dengan Asam Asetat) Di Puskesmas Jatinegara Tahun 2013) (Analisa Data Sekunder). Tesis Universitas Esa Unggul. http://digilib.esaunggul.ac.id1063.html

WHO/ICO. 2013. Comprehensive Cervical Cancer Prevention and Control a Healthier Future for Girls and Women: Summary Report update 2013. WHO ; 2013.

Yunidar, Y. 2013. Hubungan Tingkat Pengetauan Ibu tentang Kanker Serviks Dengan Perilaku Pemeriksaan Papsmear Di Puskesmas lumbulharjo II Kota Yogyakarta Tahun 2013. Naskah Publikasi Unisa. Retrieved at http://opac.say.ac.id/1459/. 